\title{
Persistent reduction of pancreatic Beta-cell mass after a limited period of protein-energy malnutrition in the young rat*
}

\author{
I.Swenne ${ }^{1,2}$, L. A.H. Borg ${ }^{1}$, C.J.Crace ${ }^{3}$ and A.Schnell Landström ${ }^{1}$ \\ 'Department of Medical Cell Biology, Uppsala University, ${ }^{2}$ Department of Paediatrics, Uppsala University Children's Hospital, Uppsala, \\ Sweden; ${ }^{3}$ Department of Paediatrics, University of Sheffield, Sheffield, UK
}

\begin{abstract}
Summary. Kwashiorkor, the human disease of proteinenergy malnutrition, has been implicated in the aetiology of malnutrition-related diabetes mellitus, a form of diabetes not uncommon in developing countries. We have previously demonstrated that temporary protein-energy malnutrition in young rats causes a persisting impairment of insulin secretion. The present study investigates whether this secretory deficiency is accompanied by structural alterations of the endocrine pancreas. Three-week-old rats were weaned onto semi-synthetic diets containing either $15 \%$ or $5 \%$ protein and these diets were maintained for 3 weeks. From 6 weeks of age all rats were fed a commercial chow containing $18 \%$ protein. The endocrine pancreas was investigated by light and electron microscopic morphometry at 3,6 and 12 weeks of age. In rats not subjected to protein-energy malnutrition
\end{abstract}

there was a progressive increase, with age, of total pancreatic Beta-cell weight and individual Beta-cell size. In 6-week-old rats fed the low protein diet total pancreatic Beta-cell weight and individual Beta-cell size were diminished. In 12-weekold rats previously fed the low protein diet total Beta-cell weight remained lower compared to control rats. It is concluded that protein-energy malnutrition early in life may result in a diminished reserve for insulin production. This may predispose to glucose intolerance or even diabetes in situations with an increased insulin demand.

Key words: Malnutrition-related diabetes mellitus, kwashiorkor, protein-calorie malnutrition, rat, pancreatic islets, pancreatic Beta cell, insulin, light microscopy, electron microscopy, morphometry.
The relationship between affluent food supply, obesity and diabetes mellitus is well known and has been the subject of numerous studies. The observation made in 1907 [1] that the spectrum of diabetes in tropical regions of the Third World differs from that in western society and that the disease may be related to malnutrition is not as well recognized. However, in recent years the malnutritionrelated diabetic syndromes have been delineated and are now regarded as separate entities [2]. The exact role of malnutrition in the aetiology and pathogenesis of these types of diabetes remains obscure [3].

Kwashiorkor, the disease of protein malnutrition in the young, is characterized by, among other symptoms and signs, impaired glucose tolerance and a diminished or even absent insulin secretory response to glucose [4-20]. This appears to be a feature typical of protein deficiency, since balanced malnutrition, as in marasmus, has little or

\footnotetext{
* This work was presented in part at the 26th Annual Meeting of the European Association for the Study of Diabetes in Copenhagen, Denmark 10-13 September 1990
}

no effect on glucose tolerance and insulin secretion $[7,9$, $11,12,15,18]$. Following nutritional rehabilitation, patients with kwashiorkor show a rapid improvement of glucose tolerance and insulin secretory response to glucose within weeks but short-term recovery remains incomplete [8-11, 13-16, 20]. Long-term follow-up has been difficult for practical reasons and the outcome influenced by socioeconomic factors and diet following the immediate recovery from malnutrition. The studies available are contradictory and suggest either complete normalization [11, $18,21]$ or a persisting impairment of glucose tolerance $[22,23]$.

The rapid initial recovery of glucose homeostasis upon treatment of kwashiorkor suggests a reversible functional impairment of the pancreatic Beta cell. However, if dimunition of Beta-cell mass were to be shown, the case for protein deficiency in the aetiology of malnutrition-related diabetes would be strengthened [3]. Histopathological investigations of the endocrine pancreas of children who have died during the acute phase of kwashiorkor are confusing since hypertrophic [24-28], normal [29-33] and atrophic $[4,24,26,34,35]$ pancreatic islets have been re- 
ported. Studies of the endocrine pancreas in patients who have suffered from kwashiorkor but subsequently recovered are to our knowledge not available. Thus, studies in man do not give a clear indication as to whether proteinenergy malnutrition causes structural alterations of the pancreatic islets.

The stunting of growth, the impaired glucose tolerance and blunted insulin secretory response to glucose of kwashiorkor can be reproduced in animal models of proteinenergy malnutrition [36-43]. Following nutritional rehabilitation growth is resumed, glucose tolerance normalized but a lowered capacity for insulin secretion persists $[41,42,44]$. Reports on the histopathology of the pancreatic islets during experimental protein-energy malnutrition are again divergent suggesting hypertrophy [45], no change $[46,47]$ or atrophy $[48-53]$. Quantitative morphometry at light and electron microscopic levels was used here to study the structural alterations in the pancreatic Beta cell of the rat during experimental proteinenergy malnutrition and after nutritional rehabilitation.

\section{Materials and methods}

\section{Diets}

Pelleted semi-synthetic diets were made by Ewos (Södertälje, Sweden) as previously described in detail [54]. They contained either $15 \%$ protein (control or " $\mathrm{C}$ " diet) or $5 \%$ protein (low protein or "LP" diet). The restriction of protein content in the LP diet was compensated for by increasing the proportion of carbohydrate. Diets were thus isoenergetic and identical except for their protein content. The commercial chow R3 (Ewos) contained (weight/weight [w/w]) $18 \%$ protein, $5 \%$ fat, $52 \%$ carbohydrates and $3.5 \%$ fibre. R3 pellets and semi-synthetic $C$ diet support growth of young rats to the same extent [44].

\section{Animals}

Sprague-Dawley rats were obtained from a local colony. Animals had free access to R3 pellets and tap water throughout breeding, gestation and lactation. Male rats were caged overnight with females and pregnancy confirmed by the presence of sperm in vaginal smears on the following morning, designated day 0 of pregnancy. Pregnant rats were caged individually and spontaneous delivery took place on day 22 of pregnancy. The day after delivery large litters were reduced to 12 pups. Litters of less than 6 were not used. At 21 days of age, male rats were weaned onto either $\mathrm{C} \operatorname{diet}(\mathrm{C}$ rats) or LP $\operatorname{diet}$ (LP rats). These diets were fed ad libitum for 3 weeks when both $\mathrm{C}$ and LP rats, at the age of 6 weeks, returned to a diet of $R 3$ pellets up to the end of the experiment at 12 weeks of age. Rats fed the LP diet reduced their food intake to one-third the amount consumed by $\mathrm{C}$ rats (C.J. Crace, unpublished observation). The deficiency state induced should therefore be regarded as a combined protein-energy malnutrition rather than as pure protein deficiency $[55,56]$.

\section{Light microscopy and light microscopic morphometry}

Rats were weighed and killed by cervical dislocation at 3,6 and 12 weeks of age. Pancreatic glands were rapidly dissected free from surrounding tissues, weighed and fixed by immersion in Bouin's fluid. The fixed tissue was embedded in paraffin according to a standardized protocol, cut into $7 \mu \mathrm{m}$ thick sections, and mounted on glass slides. Insulin was demonstrated with the unlabelled peroxi- dase-anti-peroxidase technique [57]. The primary antibody was raised in guinea pigs against bovine insulin (ICN ImmunoBiologicals, Lisle, Ill., USA). Secondary antibodies and peroxidase-antiperoxidase complex were from Dakopatts (Glostrup, Denmark). The immunostained sections were lightly counterstained with haematoxylin. The specificity of the immunostaining was tested according to Goldman [58] and included the application of primary antisera adsorbed with $100 \mathrm{ng} / \mathrm{ml}$ insulin, glucagon, somatostatin or pancreatic polypeptide.

To obtain an estimate of the Beta-cell volume fraction of the pancreas, each gland was sectioned throughout. To avoid bias due to regional variations in islet distribution and cell composition [59] sections used for measurements were selected by systematic random sampling. Every 50th section was taken from glands of 3-week-old weanlings and 6-week-old LP rats, every 100th section from glands of 6-week-old C rats and every 150 th section from glands of 12 -weekold $\mathrm{C}$ and LP rats. This sampling procedure yielded $6-12$ sections from each pancreas.

The Beta-cell volume fraction was determined by planimetric analysis using a MOP-Videoplan image analysis system (Kontron Bildanalyse, Munich, FRG). The sectional area of total pancreatic and non-pancreatic tissue, mostly lymph nodes and adipose tissue, was measured at a magnification of $156 \times$, and the area of insulinpositive cells at a magnification of $470 \times$. Crude pancreatic weight was corrected for the proportion of non-pancreatic tissue in the sections. In the following "pancreatic weight" refers to this corrected value. On the assumption that endocrine and exocrine pancreas differ only slightly in density [60], Beta-cell weight was calculated from the pancreatic weight and Beta-cell volume fraction. To allow comparison between animals of different sizes, Beta-cell weight was finally expressed per unit body weight.

\section{Electron microscopy and ultrastructural morphometry}

Rats, aged 3,6 or 12 weeks, were killed by retrograde perfusion with $2.5 \%$ (volume/volume $[\mathrm{v} / \mathrm{v}]$ ) glutaraldehyde in a phosphate buffer, $\mathrm{pH} 7.2$, through the aorta under sodium pentobarbital anaesthesia. The pancreatic glands were quickly removed and kept immersed in fixation medium. After postfixation in $1 \%(\mathrm{w} / \mathrm{v})$ osmium tetroxide the tissue was embedded in Epon 812 [61]. The pancreatic islets were identified in semithin sections stained with $1 \%(\mathrm{w} / \mathrm{v})$ toluidine blue in $25 \mathrm{mmol} / 1$ disodium tetraborate. Ultrathin sections were prepared and contrasted with uranyl acetate [62] and lead citrate [63]. Electron microscopy was carried out using a Jeol $100 \mathrm{~B}$ transmission electron microscope (Japan Electron Optics Laboratory Co., Tokyo, Japan) with the magnification calibrated against a diffraction grating replica with 28800 lines per inch (Ernest F. Fullam, Latham, NY, USA).

Two ultrathin sections, cut at least $20 \mu \mathrm{m}$ apart, were obtained by random selection from one islet from each of four rats in every experimental group. For each experimental group a total of 32 electron micrographs were taken. The fields were distributed over the sections by systematic random sampling.

In the morphometric analysis of pancreatic Beta cells, endocrine non-Beta-cells and non-endocrine tissue were excluded from the measurements. The volume of Beta cells per unit tissue volume $\left(V_{v c}\right)$ was thus by definition equal to unity. The volume of Beta-cell nuclei per unit tissue volume $\left(V_{V N}\right)$, the surface area of Beta cells per unit tissue volume $\left(\mathrm{S}_{\mathrm{vc}}\right)$, the number of Beta cells per unit tissue volume $\left(\mathrm{N}_{\mathrm{vC}}\right)$ and secondary morphometric parameters were determined as previously described [64].

\section{Statistical analysis}

Results are given as means \pm SEM. Differences between $N$ and LP rats were evaluated using Student's two-tailed $t$-test for independent observations. 
Table 1. Morphometric parameters of rats fed diets with normal (C) or low (LP) protein content between 3 and 6 weeks of age

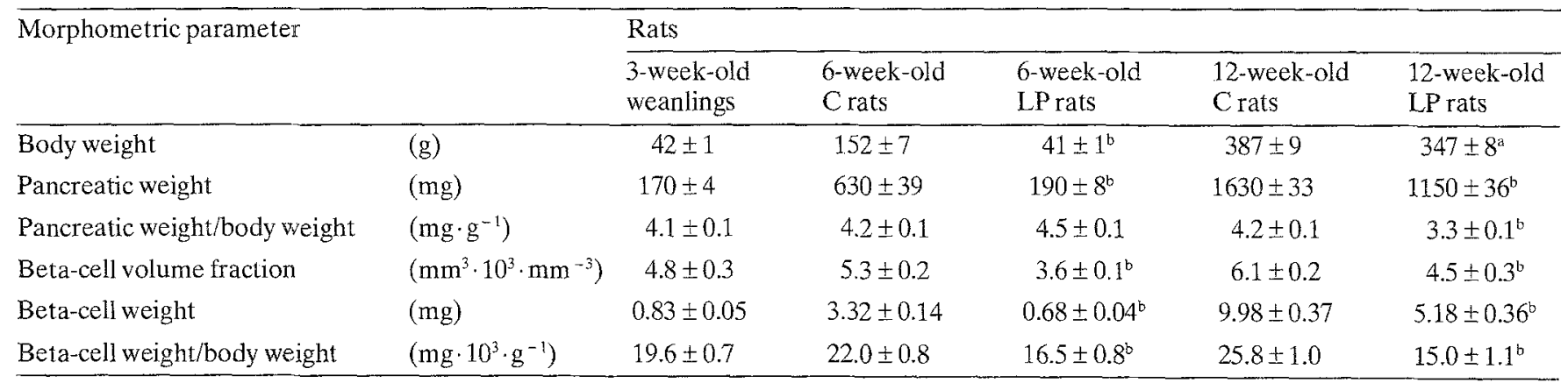

${ }^{\mathrm{a}} p<0.01 ;{ }^{\mathrm{b}} p<0.001$. Differences between $\mathrm{C}$ rats and LP rats were evaluated by Student's $t$-test. The results are given as mean values $\pm \mathrm{SEM}$ for $7-8$ rats

\section{Results}

Three-week-old rats weaned onto the $\mathrm{C}$ diet rapidly increased in weight and an almost four-fold weight gain was noted up to 6 weeks of age (Table 1). Rats weaned onto the LP diet did not gain weight. Following refeeding of standard chow at 6 weeks of age the LP rats resumed growth but at 12 weeks they still remained smaller than $C$ rats.

Light microscopic investigation of pancreatic sections from $\mathrm{C}$ rats showed a well-preserved endocrine and exocrine morphology which changed little with age. At 6 weeks of age the pancreatic islets of LP rats appeared small and with tightly packed cells. There were no signs of leucocyte infiltration, nuclear pycnosis, or cell fragmentation and death. At 12 weeks of age the pancreas of LP rats had recovered and could not be distinguished from that of 12-week-old C rats.

Light microscopic morphometry showed that the volume fraction of Beta cells in the pancreas increased with age in $\mathrm{C}$ rats and a more than ten-fold increase of total Beta-cell mass was achieved between 3 and 12 weeks of age (Table 1). When expressed per unit body weight Betacell weight increased by $25 \%$ between 3 and 12 weeks of age.

At 6 weeks of age, at the end of the period on LP diet, the Beta-cell volume fraction in the pancreas of LP rats had decreased to two-thirds that of C rats (Table 1). Total Beta-cell mass was also reduced and, when expressed per unit of body weight, only $75 \%$ of that of 6-week-old C rats. During the recovery period between 6 and 12 weeks of age pancreatic Beta-cell volume fraction increased in LP rats but reached only $75 \%$ of that of 12 -week-old $C$ rats. Total Beta-cell mass of LP rats also remained lower and was only one half that of $\mathrm{C}$ rats at 12 weeks of age, and when expressed per unit body weight, only $60 \%$ that of $\mathrm{C}$ rats.

At the ultrastructural level Beta cells could be identified by their secretory granule morphology. In 3-week-old weanling rats Beta cells had rounded nuclei with dense heterochromatin distributed along the inside of the nuclear membrane (Fig. 1A). Large nucleoli were seldom observed, the synthetic apparatus, consisting of the endoplasmic reticulum and Golgi complex, was easily identified and secretory granules abundant. At 6 weeks of age the Beta cells of $\mathrm{C}$ rats had larger nuclei with little or no condensed chromatin, large nucleoli and the synthetic apparatus was usually prominent (Fig. 1B). There was a considerable variation in secretory granule content and secondary lysosomes of a crinophagic type were common. At 12 weeks of age the ultrastructural morphology of Beta cells of $\mathrm{C}$ rats was similar to that at 6 weeks of age (Fig. 1C).

The Beta cells of 6-week-old LP rats were small and their nuclei contained large amounts of condensed chromatin but no nucleoli (Fig. 1D). The cytoplasm contained small numbers of secretory granules, a small Golgi complex but a relatively large endoplasmic reticulum. There were no signs of nuclear pycnosis or cell disintegration and death. At 12 weeks of age the Beta cells of LP rats still retained some nuclear heterochromatin and nucleoli could be seen (Fig.1E). The secretory apparatus was well developed and the content of secretory granules had increased compared to 6-week-old LP rats.

Ultrastructural morphometry showed that the average volume of individual Beta cells $\left(\mathrm{V}_{\mathrm{VO}} / \mathrm{N}_{\mathrm{VC}}\right)$ almost doubled between 3 and 12 weeks of age in $C$ rats (Table 2). The average nuclear volume of the Beta cells $\left(\mathrm{V}_{\mathrm{VN}} / \mathrm{N}_{\mathrm{VC}}\right)$ also increased but only by $24 \%$ over the same period.

By contrast, at 6 weeks of age the average Beta-cell volume $\left(\mathrm{V}_{\mathrm{VC}} / \mathrm{N}_{\mathrm{VC}}\right)$ of LP rats was only two-thirds that of $\mathrm{C}$ rats (Table 2). The average nuclear volume $\left(\mathrm{V}_{\mathrm{VN}} / \mathrm{N}_{\mathrm{VC}}\right)$ was also diminished in comparison with the 6-week-old $\mathrm{C}$ rats. Following refeeding both average Beta-cell volume $\left(\mathrm{V}_{\mathrm{VO}} \mathrm{N}_{\mathrm{VC}}\right)$ and average nuclear volume $\left(\mathrm{V}_{\mathrm{VN}} / \mathrm{N}_{\mathrm{VC}}\right)$ of LP rats increased and did not differ significantly from $\mathrm{C}$ rats at 12 weeks of age.

\section{Discussion}

The increase with age of total Beta-cell mass in C rats confirms previous investigations of Beta-cell growth $[65,66]$. The combined data of total Beta-cell mass and individual Beta-cell size indicate that approximately one half of the expansion of Beta-cell mass is due to an increase of Betacell number and the rest depends on a doubling of Betacell size. Previous functional studies have shown that the insulin secretory response matures after weaning and develops further throughout adult life $[44,67]$. The replica- 

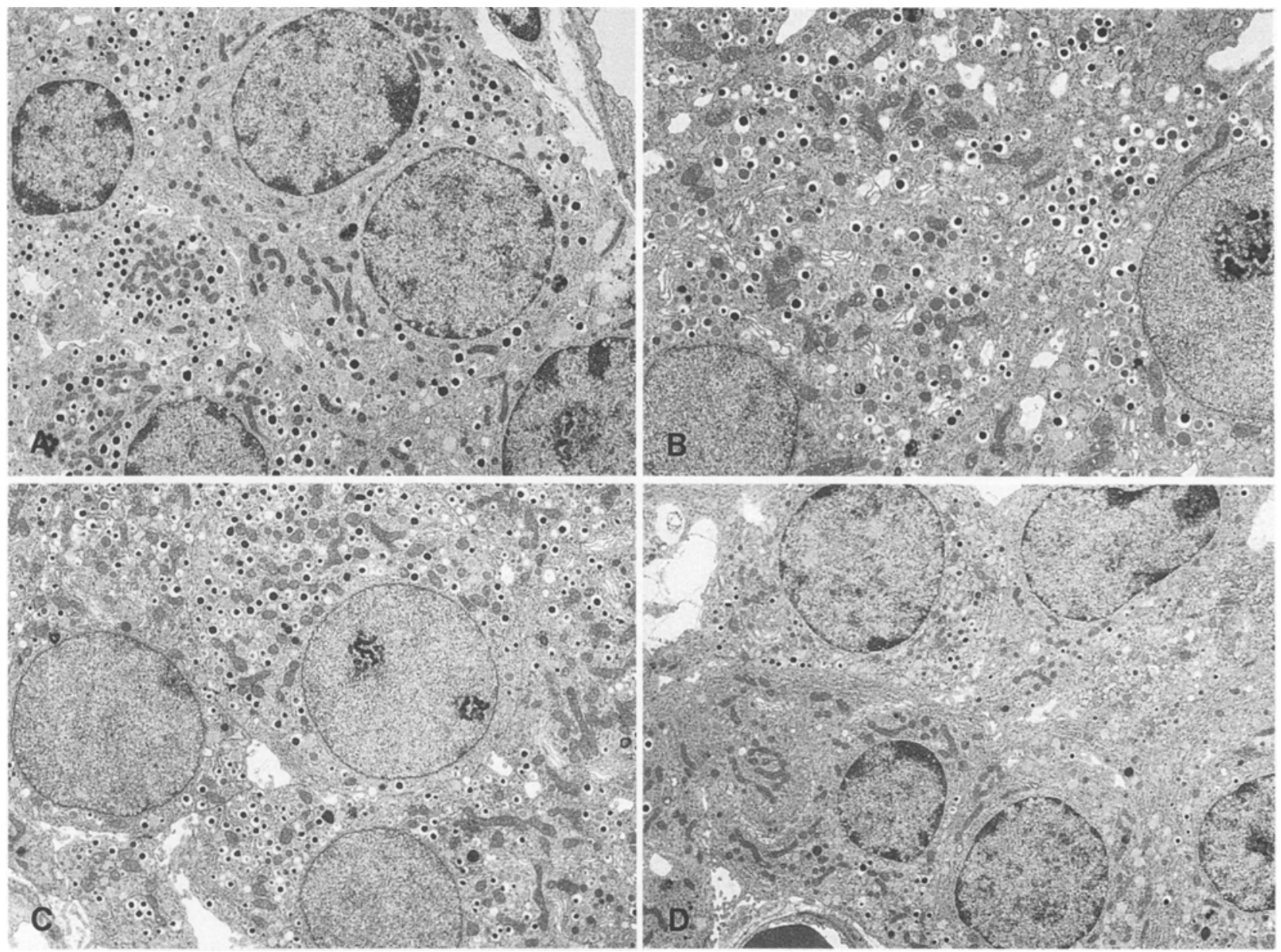

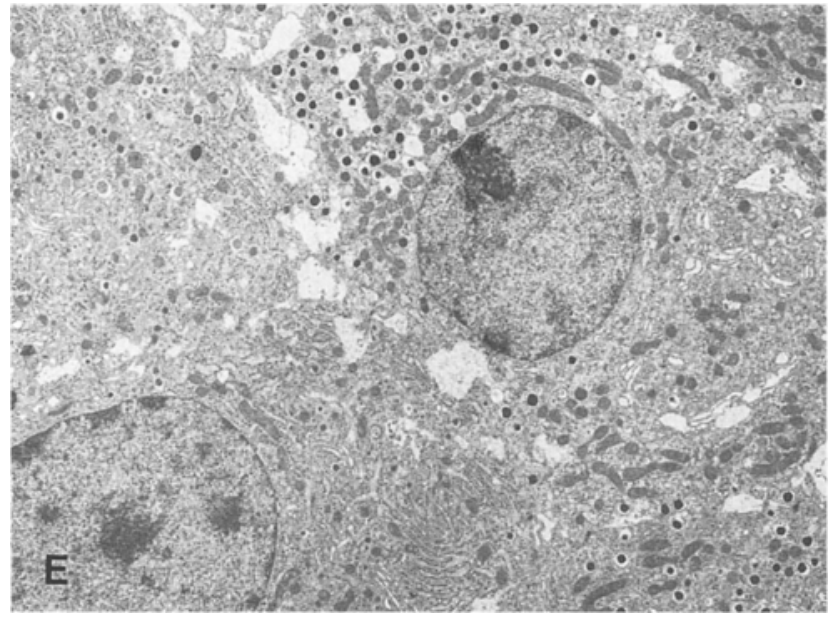

tion, growth and functional development of the Beta cells of $\mathrm{C}$ rats thus shows that the islet organ has considerable plasticity and adapts to variations in functional demand during development [68].

In 6-week-old LP rats total islet volume was diminished and the Beta cells showed ultrastructural signs of atrophy confirming previous observations of small Beta cells with hyperchromatic nuclei but lack of degenerative changes and signs of cell death in experimental protein-energy malnutrition [49,51-53]. The measurements of total Betacells mass and individual Beta-cell size indicate that total
Fig.1A-E. Electron micrographs of pancreatic Beta cells from a 3-week-old weanling rat (A), a 6-week-old control rat (B), a 12-weekold control rat (C), a 6-week-old LP rat (D), and a 12-week-old LP rat (E). $\times 4100$. At 3 weeks of age control rats were weaned onto semi-synthetic diet containing $15 \%$ protein and LP rats on diet containing $5 \%$ protein. From 6 weeks of age and onwards both groups of rats were fed a standard rat chow containing $18 \%$ protein

Beta-cell number had not increased in LP rats between 3 and 6 weeks of age. It is notable that early experimental studies [45-47] suggesting hypertrophy or no changes of the islets were not quantitative and focussed on exocrine pancreas rather than pancreatic islets. The consequence of experimental protein-energy malnutrition thus appears to be inhibition of replication and atrophy of the Beta cells. In this context it should, however, be noted that the reduction of Beta-cell mass demonstrated is not sufficient to explain the severely blunted insulin secretory response to glucose in vivo and in vitro $[42,44]$. Changes in Beta- 
Table 2. Morphometric parameters of Beta cells in pancreatic islets of rats fed diets with normal (C) or low (LP) protein content between 3 and 6 weeks of age

\begin{tabular}{|c|c|c|c|c|c|c|}
\hline \multicolumn{2}{|c|}{ Morphometric parameter } & \multicolumn{5}{|l|}{ Rats } \\
\hline & & $\begin{array}{l}\text { 3-week-old } \\
\text { weanlings }\end{array}$ & $\begin{array}{l}\text { 6-week-old } \\
\text { Crats }\end{array}$ & $\begin{array}{l}\text { 6-week-old } \\
\text { LP rats }\end{array}$ & $\begin{array}{l}12 \text {-week-old } \\
\text { C rats }\end{array}$ & $\begin{array}{l}\text { 12-week-old } \\
\text { LP rats }\end{array}$ \\
\hline $\mathrm{S}_{\mathrm{VC}}$ & $\left(\mu \mathrm{m}^{2} \cdot \mu \mathrm{m}^{-3}\right)$ & $0.515 \pm 0.021$ & $0.459 \pm 0.018$ & $0.556 \pm 0.017^{\mathrm{d}}$ & $0.433 \pm 0.016$ & $0.446 \pm 0.013$ \\
\hline $\mathrm{N}_{\mathrm{VC}}$ & $\left(10^{3} \cdot \mu \mathrm{m}^{-3}\right)$ & $1.04 \pm 0.56$ & $0.87 \pm 0.08$ & $1.32 \pm 0.08^{\mathrm{d}}$ & $0.56 \pm 0.11$ & $0.81 \pm 0.06^{\mathrm{b}}$ \\
\hline $\mathrm{V}_{\mathrm{vC}} / \mathrm{N}_{\mathrm{vC}}$ & $\left(\mu \mathrm{m}^{3}\right)$ & $960 \pm 512$ & $1150 \pm 106$ & $756 \pm 47^{c}$ & $1790 \pm 349$ & $1240 \pm 86$ \\
\hline $\mathrm{V}_{\mathrm{VN}}$ & $\left(\mu \mathrm{m}^{3} \cdot \mu \mathrm{m}^{-3}\right)$ & $0.18 \pm 0.02$ & $0.16 \pm 0.01$ & $0.17 \pm 0.01$ & $0.12 \pm 0.01$ & $0.13 \pm 0.01$ \\
\hline
\end{tabular}

${ }^{a} \mathrm{~V}_{\mathrm{VC}}$ is by definition assigned the value of 1.000 as explained in the Materials and methods section.

${ }^{b} p<0.05 ;{ }^{c} p<0.01 ;{ }^{d} p<0.001$. Differences between $C$ rats and LP rats were evaluated by Student's $t$-test. The results are given as mean values \pm SEM of 32 observations.

cell function must also be investigated to explain this effect of protein-energy malnutrition.

The major novel observation of the present investigation is that temporary protein-energy malnutrition in young rats causes a dimunition of pancreatic Beta-cell mass which is not compensated for despite apparent adequate nutritional rehabilitation. Although at 12 weeks of age LP rats had increased Beta-cell number almost fivefold and total Beta-cell mass eight-fold they still did not reach the values of $\mathrm{C}$ rats. Since the rats grow at a normal rate and have a normal glucose tolerance [42], it could be argued that the Beta cells have only adapted to a new metabolic state. However, perfusion of the pancreas from 12-week-old LP rats has shown loss of first phase insulin release and reduction of the second phase [44]. It would therefore appear that the protein-energy malnutrition has a direct effect on the Beta cells and leaves them with not only a blunted insulin secretory response but also with a diminished capacity for Beta-cell growth and replication.

Beta-cell atrophy appears to be a feature typical of protein deficiency. If rats are energy restricted by feeding them a diet of adequate nutritional composition but in amounts reduced to stunt growth, the proportion of Betacell mass to body weight is not decreased [69-71] and the insulin secretory response to glucose is maintained [72]. This parallels the situation seen in human disease, since in marasmus insulin secretion is preserved but in kwashiorkor, insulin secretion is impaired $[11,12,15,18]$. The pathology of the pancreatic islets in human kwashiorkor is controversial but may depend on the duration of proteinenergy deficiency [24]. Taken together, available data from morphological and functional studies in animals and humans suggest that kwashiorkor of some standing causes atrophy of the pancreatic Beta cells. It is not known whether adults who suffered from kwashiorkor in childhood have a reduced Beta-cell mass or other persisting alterations of the endocrine pancreas. The epidemiological evidence for a relationship between protein-energy malnutrition and malnutrition-related diabetes nevertheless makes it tempting to speculate that, if the reserves for insulin production are diminished by malnutrition, impaired glucose tolerance or even diabetes may develop if
The morphometric parameters are:

$V_{v c}$, volume of Beta-cells per unit tissue volume;

$S_{V c}$, surface area of Beta-cells per unit tissue volume;

$\mathrm{N}_{\mathrm{VC}}$, number of Beta-cells per unit tissue volume;

$\mathrm{V}_{\mathrm{v}} \mathrm{N}_{\mathrm{vc}}$, average Beta-cell volume;

$V_{V N}$, volume of Beta-cell nuclei per unit tissue volume and

$\mathrm{V}_{\mathrm{VN}} / \mathrm{N}_{\mathrm{Vc}}$, average Beta-cell nuclear volume

demands on insulin secretion are increased by intercurrent illness or other, hitherto unknown, environmental factors.

Acknowledgements. The authors are indebted to Ms C. Bittkowski, Ms E. Törnelius and Ms K. Flink for expert technical assistance. This study was supported by the Swedish Diabetes Association, the Family Ernfors Fund, the Swedish Society of Medical Sciences, the Swedish Hoechst Diabetes Fund, the Nordisk Insulin Foundation Committee and the Swedish Medical Research Council (grants 12P-6947, 19P-9314, 12X-6538 and 12X-109).

\section{References}

1. Charles RH, Bose RKC, Bose CL, Chakravarti S, Devendranath $\mathrm{R}$, Sandwith FN (1907) Diabetes in the tropics. Br Med J 2: 10511064

2. WHO study group (1985) Diabetes mellitus. Technical Report Series 727. World Health Organization, Geneva, pp 20-25

3. Rao RH (1988) Diabetes in the undernourished: coincidence or consequence? Endocr Rev 9:67-87

4. Holmes EG, Trowell HC (1948) Formation of hepatic glycogen in normal Africans and in those suffering from malignant malnutrition. Lancet I: 395-398

5. Aballí AJ (1950) Disturbances of carbohydrate metabolism in infantile malnutrition. Rev Cubana Pediatr 22: 509-541

6. Slone D, Taitz LS, Gilchrist GS (1961) Aspects of carbohydrate metabolism in kwashiorkor with special reference to spontaneous hypoglycemia. Br Med J 1:32--34

7. Bowie MD (1964) Intravenous glucose tolerance in kwashiorkor and marasmus. S Afr Med J 38: 328-329

8. Baig HA, Edozien JC (1965) Carbohydrate metabolism in kwashiorkor. Lancet II: 662-665

9. Hadden DR (1967) Glucose, free fatty acids, and insulin interrelations in kwashiorkor and marasmus. Lancet II: 589-593

10. James WPT, Coore HG (1970) Persistent impairment of insulin secretion and glucose tolerance after malnutrition. Am J Clin Nutr 23:386-389

11. Becker DJ, Pimstone BL, Hansen JDL, Hendricks S (1971) Insulin secretion in protein-calorie malnutrition. I. Quantitative abnormalities and response to treatment. Diabetes 20: 542-551

12. Godard C, Zahnd GR (1971) Growth hormone and insulin in severe infantile malnutrition. II. Plasma insulin and growth hormone during intravenous glucose tolerance test. Helv Paediatr Acta 26: 276-285 
13. Milner RDG (1971) Metabolic and hormonal responses to glucose and glucagon in patients with infantile malnutrition. Pediatr Res 5: 33-39

14. Alleyne GAO, Trust PM, Flores H, Robinson H (1972) Glucose tolerance and insulin sensitivity in malnourished children. $\mathrm{Br} \mathrm{J}$ Nutr 27: 585-592

15. Becker DJ, Pimstone BL, Hansen JDL, MacHutchon B, Drysdale D (1972) Patterns of insulin response to glucose in proteincalorie malnutrition. Am J Clin Nutr 25: 499-505

16. Milner RDG (1972) Insulin secretion in human protein-calorie deficiency. Proc Nutr Soc 31: 219-223

17. Rao KSJ, Raghuramulu N (1972) Insulin secretion in kwashiorkor. J Clin Endocrinol Metab 35: 63-66

18. Pimstone B, Becker D, Weinkowe C, Mann M (1973) Insulin secretion in protein-calorie malnutrition. In: Gardner LI, Amacher P (eds) Endocrine aspects of malnutrition. Raven Press, Santa Ynez, pp 289-305

19. Becker DJ, Pimstone BL, Hansen JDL (1975) The relation between insulin secretion, glucose tolerance, growth hormone, and serum proteins in protein-calorie malnutrition. Pediatr Res 9: 35-39

20. Parra A, Klish W, Cuellar A et al. (1975) Energy metabolism and hormonal profile in children with edematous protein-calorie malnutrition. J Paediatr 87:307-314

21. Kajubi SK (1972) The endocrine pancreas after kwashiorkor. Am J Clin Nutr 25: 1140-1142

22. Cook GC (1967) Glucose tolerance after kwashiorkor. Nature 215: $1295-1296$

23. Cook GC (1968) Glucose and starch tolerance after recovery from kwashiorkor. Metab Clin Exp 17: 1073-1083

24. Davies JNP (1948) The essential pathology of kwashiorkor. Lancet I: $317-320$

25. Camain R,Pierchon M(1954) Malnutritionin African mothers, infants and young children. Report of second inter-African conference on nutrition. H. M. Stationary Office, London, pp 146-151

26. Trowell HC, Davies JNP, Dean RFA (1954) Kwashiorkor. Edward Arnold, London

27. Waterlow JC (1955) Pathology and protein malnutrition. In: Waterlow JC (ed) Protein malnutrition. University Press, Cambridge, pp $68-136$

28. Tejada C, Russfield AB (1957) A preliminary report on the pathology of the pituitary gland in children with malnutrition. Arch Dis Child 32: 343-346

29. Waterlow JC (1948) Fatty liver disease in infants in the British West Indies. Medical Research Council Special Report Series No 263. British Medical Research Council, London, pp 4-84

30. Hartz PH (1949) Pancreatic atrophy in infants with fatty liver. Doc Neerl Indones Morb Trop 1: 41-49

31. Bablet J, Canet J (1952) Etude histopathologique des troubles de la nutrition chez le nourrisson et l'enfant vietnamien. Ann Inst Pasteur 83: 595-607

32. Davies JNP (1952) Nutrition and nutritional diseases. Annu Rev Med 3: 99-133

33. Campbell JAH (1956) The morbid anatomy of infantile malnutrition in Cape Town. Arch Dis Child 31: 310-314

34. Bablet J, Normet LL (1937) Les lésions histopathologique de la bouffisure d'Annam. Bull Acad Natl Med Paris 117:242-245

35. Normet L (1937) La bouffisure d'Annam. Maladie de carance. Bull Soc Sci Hyg Aliment 25; 153-170

36. Heard CRC (1966) Effects of severe protein-calorie deficiency on the endocrine control of carbohydrate metabolism. Diabetes 15: 78-89

37. Heard CRC, Turner MR (1967) Glucose tolerance and related factors in dogs fed diets suboptimal in protein value. Diabetes 16: 96-107

38. Khardori R, Bajaj JS, Deo MG, Bansal DD (1980) Insulin secretion and carbohydrate metabolism in experimental protein malnutrition. J Endocrinol Invest 3: 273-278

39. Younoszai R, Dixit PK (1980) Decreased insulin secretion by isolated pancreatic islets from rats fed $4 \%$ protein diet. Proc Soc Exp Biol Med 164:317-321
40. Levine LS, Wright PG, Marcus F (1983) Failure to secrete immunoreactive insulin by rats fed a low protein diet. Acta Endocrinol 102: $240-245$

41. Okitolonda W, Brichard SM, Henquin JC (1987) Repercussions of chronic protein-calorie malnutrition on glucose homeostasis in the rat. Diabetologia 30: 946-951

42. Swenne I, Crace CJ, Milner RDG (1987) Persistent impairment of the insulin secretory response to glucose in adult rats after limited period of protein-calorie-malnutrition early in life. Diabetes 36: 454-458

43. Okitolonda W, Brichard SM, Pottier AM, Henquin JC (1988) Influence of low-and high-protein diets on glucose homeostasis in the rat. Br J Nutr 60: 509-516

44. Swenne I, Crace CJ, Jansson L (1988) Intermittent protein-calorie malnutrition in the young rat causes long-term impairment of the insulin secretory response to glucose in vitro. J Endocrinol 118: 295-302

45. Kristal J (1947) Cystic and other changes in the pancreas of rats fed a diet of mealie meal and sour milk. S Afr J Med Sci 12: 47-52

46. Véghelyi PV, Kemény TT, Pozsonyi J, Sós J (1950) Dietary lesions of the pancreas. Am J Dis Child 79: 658-665

47. Wachstein M, Meisel E (1954) Relation of dietary protein levels to pancreatic damage in the rat. Proc Soc Exp Biol Med 85: 314 317

48. Adams GVM, Fernand VSV, Schneiden H (1958) Histochemistry of a condition resembling kwashiorkor produced in rodents by a low protein diet-high carbohydrate diet (cassava). Br J Exp Pathol 39: 393-404

49. Stewart RJC, Heard CRC (1959) Pancreatic islet cells and bloodsugar regulation in pigs maintained on low-protein diets. Proc Nutr Soc 18: 10-11

50. Volk BW, Lazarus SS (1960) Rabbit pancreas in protein malnutrition (experimental kwashiorkor) and after cortisone administration. Am J Pathol 37: 121-135

51. Platt BS, Stewart RJC (1967) Experimental protein-calorie deficiency: histopathological changes in the endocrine glands of pigs. J Endocrinol 38: 121-143

52. Heard CRC, Stewart RJC (1971) Protein-calorie-deficiency and disorders of the endocrine glands. Hormones 2: 40-64

53. Weinkowe C, Weinkowe E, Timme A, Pimstone B (1977) Pancreatic islets in malnourished rats. Quantitative histologic and electron microscopic findings. Arch Pathol Lab Med 101: 266269

54. Syme G (1982) The effect of protein-deficient isoenergetic diet on the growth of the rat jejunal mucosa. Br J Nutr 48:25-36

55. Cabak V, Dickerson JWT, Widdowson EM (1963) Response of young rats to deprivation of protein or of calories. Br J Nutr 17 : $601-616$

56. Hill DE, Holt AB, Parra A, Cheek DB (1970) The influence of protein-calorie versus calorie restriction on the body composition and cellular growth of muscle and liver in weanling rats. Johns Hopkins Med J 127: 146-163

57. Erlandsen SL, Parsons JA, Burke JP, Redick JA, Van Orden DE, Van Orden LS (1975) A modification of the unlabeled antibody enzyme method using heterologous antisera for light microscopic and ultrastructural localization of insulin, glucagon and growth hormone. J Histochem Cytochem 23: 666-677

58. Groldman M (1968) Fluorescent antibody methods. Academic Press, New York

59. Orci L, Baetens D, Ravazzola M, Stefan Y, Malaisse-Lague F (1976) Pancreatic polypeptide and glucagon: non-random distribution in pancreatic islets. Life Sci 19: 1811-1816

60. Buitrago A, Gylfe E, Henriksson C, Pertoft H (1977) Rapid isolation of pancreatic islets from collagenase digested pancreas by sedimentation through Percoll at unit gravity. Biochem Biophys Res Commun 79: 823-828

61. Luft $J H$ (1961) Improvements in epoxy resin embedding methods. J Biophys Biochem Cytol 9: 409-414

62. Watson ML (1958) Staining of tissue sections for electron microscopy with heavy metals. J Biophys Biochem Cytol 4: 475478 
63. Reynolds ES (1963) The use of lead citrate at high $\mathrm{pH}$ as an electron-opaque stain in electron microscopy. J Cell Biol 17: 208-212

64. Schnell AH, Borg LAH (1985) Lysosomes and pancreatic islet function. Glucose-dependent alterations of lysosomal morphology. Cell Tissue Res 239: 537-545

65. Hellman B (1959) The effect of ageing on the total volumes of the $A$ and $B$ cells in the islets of Langerhans of the rat. Acta Endocrinol 32: 92-112

66. McEvoy RC (1981) Changes in the volumes of the A-, B-, and D-cell populations in the pancreatic islets during development of the rat. Diabetes 30: $813-817$

67. Grill V, Lake W, Freinkel N (1981) Generalized dimunition in the response to nutrients as insulin-releasing agents during the early neonatal period in the rat. Diabetes 30: 56-63

68. Hellerström C (1977) Growth pattern of pancreatic islets in animals. In: Volk BW, Wellman KF (eds) The diabetic pancreas. Plenum, New York, pp 61-97

69. Haist RE (1949) Factors affecting the volume of the islands of Langerhans. Proc Am Diabetes Assoc 9: 53-62
70. Ashworth MA, Kerbel NC, Haist RE (1952) Effect of chronic caloric insufficiency on the growth of the islets of Langerhans. Am J Physiol 171:25-28

71. Dixit PK, Kaung HLC (1985) Rat pancreatic B-cells in protein deficiency: a study involving morphometric analysis and alloxan effect. J Nutr 115: $375-381$

72. Crace CJ, Swenne I, Milner RDG (1991) Long-term effects on glucose tolerance and insulin secretory response to glucose following a limited period of severe protein or energy deficiency in young rats. Upsala J Med Sci 96: 177-183

Received: 3 January 1992

and in final revised form: 9 June 1992

Dr. I. Swenne

Department of Paediatrics

Uppsala University

Children's Hospital

S-751 85 Uppsala

Sweden 